\title{
PENGARUH SENAM HAMIL TERHADAP TINGKAT KECEMASAN PADA IBU PRENATAL TRIMESTER III DI RSIA CAHAYA BUNDA
}

\author{
Dewi, NLP Arista Candra ${ }^{1 *}$; Pratiwi, Ni Made Sintha ${ }^{2}$; Astuti, Ni Luh Seri ${ }^{3}$ \\ ${ }^{1,2}$ Stikes Advaita Medika \\ *Korespondensi: aristacandra1@gmail.com
}

\begin{abstract}
Background: Anxiety is a feeling of discomfort, a feeling of fear caused by anticipation of danger. The impact of anxiety is bad for mother and fetus, so it needs to do intervention for resolving the anxiety. Pregnant gymnastics is one way to reduce anxiety in pregnant women. The purpose of this study knowing the effect of pregnancy exercise on the level of anxiety in prenatal mothers in the third trimester at the RSIA Cahaya Bunda Gerokgak Tabanan.Method: The desaign used the preexperimental design of one pretest posttest group, the research subjects were prenatal mothers in the third trimester, with non probability sampling used a purposive sampling method. The research instrument with the HARS questionnaire. Statistical tests used the Wilcoxon Test, with a confidence level of 95\% and $\mathrm{p}<0.05$.Results: The results of the pretest were moderate anxiety of $63.3 \%$ and severe anxiety $36.7 \%$, after the intervention, the results of the posttest score were mild anxiety $(60.0 \%)$, no anxiety $(36.7 \%)$ and moderate anxiety $(3.3 \%)$. The Wilcoxon analysis test results get a value of $\rho=0,000$ and the value of $\rho$ is smaller than $\alpha(5 \%)$ or 0.05 , it means there is a significant effect of pregnancy exercise on the level of anxiety in prenatal mothers in the third trimester.Conclusion: There was a decrease in the level of anxiety before the intervention was given and after the intervention was given, so that there was the influence of pregnancy exercise on the anxiety level of prenatal pregnant women in the third trimester.
\end{abstract}

Keywords: Anxiety leve;, Pregnant gymnastic; Prenatal in the third trimester

\begin{abstract}
ABSTRAK
Latar belakang:Kecemasan pada ibu prenatal trimester III merupakan perasaan khawatir seorang ibu menjelang proses persalinanya. Dampak kecemasan berpengaruh buruk untuk ibu dan janin.Sehingga perlu dilakukan intervensi untuk mengatasi kecemasan tersebut. Senam hamil salah satu cara untuk dapat menurunkan kecemasan pada ibu hamil. Tujuan penelitian ini adalah untuk mengetahui pengaruh senam hamil terhadap tingkat kecemasan pada ibu prenatal III di RSIA Cahaya Bunda Gerokgak Tabanan. Metode: Menggunakan desain penelitian pre-
\end{abstract}


eksperimental one grup pretest posttest, subjek penelitian yaitu ibu prenatal trimester III, dengan non probability sampling menggunakan metode purposive sampling. Instrument penelitian dengan kuesioner HARS. Uji statistik menggunakan Uji Wilcoxon, dengan tingkat kepercayaan $95 \%$ dan $\mathrm{p}<0,05$. Hasil: Hasil pretest didapatkan kecemasan sedang sebesar 63,3\% dan kecemasan berat 36,7\% setelah intervensi, hasil nilai posttest didapatkan kecemasan ringan $(60,0 \%)$, tidak mengalami kecemasan $(36,7 \%)$ dan kecemasan sedang $(3,3 \%)$. Hasil uji analisis Wilcoxon didapatkan nilai $\rho=0,000$ dan nilai $\rho$ lebih kecil dari $\alpha(5 \%)$ atau 0,05 yang berarti ada pengaruh yang signifikan senam hamil terhadap tingkat kecemasan pada ibu prenatal trimester III.Simpulan: Terjadi penurunan tingkat kecemasan sebelum diberikan intervensi dan setelah diberikan intervensi, sehingga ada pengaruh senam hamil terhadap tingkat kecemasan ibu hamil prenatal trimester III.

\section{Kata kunci: Senam hami;, Tingkat kecemasan; Prenatal trimester III}

\section{PENDAHULUAN}

Proses kehamilan merupakan pengalaman yang sangat ingin dirasakan oleh setiap wanita yang sudah berkeluarga. Proses dari masa kehamilan sampai masa persalinan dikenal sebagai periode sensitif, kebanyakan wanita mengalami perubahan psikologis dan emosi (Locchart \& Saputra,2014). Terdapat beberapa faktor yang mempengaruhi kehamilan yaitu faktor fisik, psikologis, sosial budaya (Kuswanti, 2014).Beban psikologis pada seorang wanita hamil, lebih banyak terjadi pada masa prenatal trimester III dibandingkan pada trimester I dan trimester II. Prenatal trimester III merupakan masa dimana bayi masih ada dalam kandungan yang telah memasuki usia kehamilan 27-40 minggu (Kuswanti Ina, 2014). Beban psikologis yang dialami ibu hamil pada masa prenatal trimester III lebih banyak terjadi pada ibu primigravida dalam menjelang persalinannya, beban psikologis tersebut salah satunya yaitu kecemasan.

Kecemasan adalah perasaan tidak nyaman atau kekhawatiran yang samar disertai respon otonom (sumber sering kali tidak spesifik atau tidak diketahui oleh individu), perasaan takut yang disebabkan oleh antisipasi terhadap bahaya (Herdman, 2016). Bulan-bulan terakhir menjelang persalinan perubahan emosi ibu semakin berubah-ubah dan terkadang menjadi tidak terkontrol. Kecemasan yang terjadi pada ibu hamil menjelang persalinannya terjadi karena ibu merasa ragu terhadap kondisi kehamilannya saat ini, takut dengan keselamatannya dan keselamatan bayinya pada 
saat persalinan atau kekhawatiran dan kecemasan akibat ketidakmampuannya dalam menjalankan tugas-tugas sebagai ibu pasca kelahiran bayinya, ibu hamil akan merasa tidak nyaman, dan merasa dirinya jelek, (Kuswanti, 2014).

Kecemasan selama masa kehamilan sampai trimester tiga apabila tidak diatasi maka akan berdampak mempengaruhi proses persalinan, pertumbuhan perkembangan janin, dapat menyebabkan bayi lahir prematur, Berat Badan Lahir Rendah (BBLR), proses persalinan lama, gangguan mental dan motorik anak (Mardjan, 2016). Kecemasan pada saat kehamilan sangat mempengaruhi kesehatan ibu dan janin.Dampak dari kecemasan tersebut begitu besar pengaruhnya bagi ibu dan janin, sehingga perlu dilakukan intervensi untuk mengatasi kecemasan pada ibu hamil tersebut. Pemerintah Indonesia melakukan upaya untuk mengatasi masalah tersebut dengan cara peningkatan pemerdayaan masyarakat melalui kegiatan kelas ibu hamil dan balita serta perencanaan persalinan dan pencegahan komplikasi, (Kemenkes RI, 2015). Senam hamil merupakan bagian dari program kelas hamil yang bertujuan mempersiapkan fisik dan mental ibu hamil dalam menghadapi persalinannya (Kemenkes RI, 2015). Menurut Hartaty (2016), olahraga merupakan salah satu cara menurunkan kecemasan, salah satunya yaitu senam hamil.

Senam hamil adalah terapi latihan gerak untuk mempersiapkan ibu hamil secara fisik, mental dan psikologis sehingga dapat melakukan persalinan spontan yang cepat dan aman (Nurdiansyah, 2011).Senam hamil selamakehamilan dapat mempersiapkan kondisi fisik yang prima saat menjelang hari persalinan tiba, yang secara tidak langsung dapat memberikan ketenangan batin, mengurangi kecemasan, dan menambah rasa percaya diri ibu dalam melakukan persalinan (Suwignyono, 2011).Senam hamil bertujuan untuk membuat elastis otot-otot dan ligament yang ada di panggul, memperbaiki sikap tubuh, mengatur kontraksi dan relaksasi, serta mengatur teknik pernafasan yang diperlukan untuk meningkatkan kesiapan fisik dan mental dalam menghadapi persalinan. Gerakkan senam hamil terkandung reflek relaksasi yang dapat mengurangi kecemasan ibu hamil.Latihan senam hamil masih didasarkan pada pedoman saat ini yaitu intensitas sedang, dan dilakukan setidaknya 3 kali dalam seminggu dalam waktu 30 menit atau lebih. 
Menurut data World Health Organization (WHO), angka kematian ibu hamil didunia pada tahun 2015 adalah sebesar 302.000 kematian. Menurut kementrian kesehatan tahun 2015-2017 kasus angka kematian ibu (AKI) di Indonesia tahun 2017 sebanyak 1712 kasus (Kemenkes RI, 2017). Besar angka kematian ibu di Provinsi Bali secara umum dalam 5 tahun terakhir berada di bawah angka nasional, dan di bawah target yang ditetapkan 100 per 100.000 kelahiran namun setiap tahunnya belum bisa di turunkan secara signifikan. Tahun 2016 angka kematian ibu mencapai 78,7\%, dan tahun 2017 turun menjadi 68,6 \% (Dinkes Bali, 2017). Angka kematian ibu di Kabupaten Tabanan Tahun 2016 yaitu mencapai 143,4 per 100.000 kelahiran hidup. Angka tersebut merupakan angka tertinggi 10 tahun terakhir dan perlu mendapat perhatian lebih dalam pelayanan kesehatan selama kehamilan, (Dinkes Bali, 2017).

Banyaknya angka kematian ibu hamil menyebabkan kecemasan, ketakutan dan gangguan psikologis pada ibu yang mengalami kehamilan.Pravelensi ibu hamil yang mengalami kecemasan di dunia dari penelitian yang dilakukan oleh Verbeek (2015) di Nikaragua yaitu sebanyak 57\%.Menurut PPNI 2013 di Indonesia terdapat 373.000 .000 orang ibu hamil dan yang mengalami kecemasan dalam menghadapi persalinan ada sebanyak 107.000.000 orang. Studi yang dilakukan Heriani 2016, menyatakan bahwa dari 45 responden yang diteliti, yang mengalami kecemasan dalam menghadapi masa menjelang persalinan sebanyak 24 responden $(53,3 \%)$ dan 21 responden $(46,7 \%)$ tidak mengalami kecemasan. Penelitian di Indonesia pada tahun 2012 hampir 76,8\% ibu mengalami kecemasan pada akhir kehamilan ibu 80\% diantaranya dialami oleh ibu primigravida dan $20 \%$ dialami oleh ibu yang multigravida.

Menurut penelitian yang dilakukan oleh Farida et al(2017)terhadap 28 primigravida trimester III yang dilakukan senam hamil selama 3 kali mendapatkan hasil penelitian bahwa rata-rata tingkat kecemasan pada kelompok yang diberikan senam hamil lebih rendah dibandingkan dengan kelompok kontrol yang tidak diberikan perlakuan. Penurunan ini signifikan secara statistik yaitu $p$-value sebesar 0,00001( $<<0,05)$. Penelitian yang dilakukan oleh Mona Khalajzadeh et alyang 
dilakukan selama 8 minggu mendapatkan hasil yang menunjukkan bahwa tidak ada perbedaan yang signifikan antara kelompok dalam kecemasan pretest $(\mathrm{p}>0,008)$ tetapi perbedaannya signifikan dalam posttest $(\mathrm{p}<0,008)$ kasus ini menunjukkan bahwa yoga memiliki dampak di kedua periode kehamilan, tetapi tidak ada perbedaan yang signifikan yang terlihat antara kecemasan pada trimester kedua dan ketiga.

Berdasarkan studi pendahuluan yang peneliti lakukan di RSIA Cahaya Bunda Gerokgak Tabanan pada bulan Desember 2018 ibu hamil trimester III yang berkunjung pada bulan Desember 2018 mencapai 145 orang. Hasil wawancara, dari 9 ibu hamil trimester III terdapat 7 orang yang mengalami kecemasan berat, 1 orang mengalami kecemasan sedang, dan 1 orang yang mengalami kecemasan ringan, serta dari 145 ibu hamil trimester III 16\% yang mengikuti senam hamil dan 84\% yang tidak mengikuti senam hamil. Tujuan dari penelitian ini yaitu untuk mengetahui pengaruh senam hamil terhadap tingkat kecemasan pada ibu prenatal trimester III di RSIA Cahaya Bunda Gerokgak Kabupaten Tabanan.

\section{METODE}

Penelitian ini menggunakan desain penelitian pre-eksperimental dengan rancangan penelitian one group pretest and posttest.Penelitian ini hanya menggunakan satu kelompok subyek, pengukuran variabel penelitian dilakukan sebelum dan sesudah dilakukan intervensi.Penelitian dilakukan untuk meneliti pengaruh senam hamil terhadap tingkat kecemasan ibu prenatal trimester III. Populasi dalam penelitian ini adalah ibu hamil trimester III yang memeriksakan kehamilannya di RSIA Cahaya Bunda Gerokgak Kabupaten Tabanan.Jumlah populasi ibu hamil trimester III pada bulan Desember2018 tercatat berjumlah 145 orang. Pengambilan sampel dilakukan dengan menggunakan caranon probability samplingdengan metode purposive sampling yaitu teknik penentuan sampel dengan pertimbangan tertentu. Sampel diambil dari semua responden yang memenuhi kriteria inklusi dan ekslusi.Sampel dalam penelitian ini berjumlah 30 responden.Penelitian dilakukan 3 kali dalam 3 minggu. 
Instrumen yang digunakan dalam penelitian ini adalah SOP dan Kuesioner. SOP digunakan sebagai panduan dalam melakukan senam hamil yang akan diberikan kepada responden. Kuesioner yang digunakan dalam penelitian ini adalah kuesioner kecemasan Hamilton Anxiety Rating Scale (HARS) yang sudah valid (Nursalam, 2017).Kuesioner tersebut terdiri dari 14 item pernyataan yang disetiap itemnya terdapat subitem.Masing-masing item memiliki nilai dari 0-4. Skor 0: tidak ada gejala, 1: Ringan (Satu gejala dari pilihan tersebut), 2: sedang (Separuh dari gejala tersebut), 3: Berat (Lebih dari separuh gejala yang ada), 4: Sangat berat (Semua gejala yang ada). Kemudian hasil skor tersebut akan dijumlahkan untuk mengetahui tingkat kecemasan responden. Penilaian tingkat kecemasan tersebut dibagi menjadi 4 tingkatan yaitu: skor <6 (Tidak ada kecemasan), 6-14 (Kecemasan ringan), 15-27 (Kecemasan sedang), >27 (Kecemasan berat), (Nursalam,2017).Pengambilan data dengan kuesioner dilakukan sebelum dan setelah responden diberikan intervensi senam hamil. Hasil data yang sudah dikumpulkan akan dilakukan tahap editing data, coding data, entry data, dan tabulasi data. Uji statistik yang digunakan dalam penelitian ini adalah dengan menggunakan uji statistik Wilcoxson untuk mengetahui pengaruh senam hamil terhadap tingkat kecemasan ibu hamil trimester III dengan membandingkan kondisi sebelum dan sesudah diberikan intervensi. Hasilnya akan disajikan dalam bentuk tabel.

\section{HASIL}

Tabel 1 Distribusi Frekuensi Responden Berdasarkan Tingkat Kecemasan Pre Dilakukan Intervensi Senam Hamil

\begin{tabular}{cccc}
\hline No & Tingkat Kecemasan Pre Senam Hamil & Frekuensi (n) & Persentase $(\%)$ \\
\hline 1 & Kecemasan sedang & 19 & 63,3 \\
2 & Kecemasan berat & 11 & 36,7 \\
\hline & TOTAL & 30 & 100.0 \\
\hline
\end{tabular}

Tabel 2 Distribusi Frekuensi Responden Berdasarkan Tingkat Kesemasan Post Dilakukan Senam Hamil

\begin{tabular}{cccc}
\hline No & Tingkat Kecemasan Post Senam Hamil & Frekuensi (n) & Persentase $(\%)$ \\
\hline 1 & Tidak ada kecemasan & 11 & 36,7 \\
2 & Kecemasan Ringan & 18 & 60,0 \\
3 & Kecemasan Sedang & 1 & 3,3 \\
\hline & TOTAL & 30 & 100,0 \\
\hline
\end{tabular}


Tabel 3 Pengaruh Senam hamil Terhadap Tingkat Kecemasan Ibu Prenatal Trimester III

\begin{tabular}{ccccc}
\hline Pengaruh & Mean Rank & Sum Of Rank & Nilai Z & Nilai P \\
\hline Pretest Posttest & & & $-4,191$ & 0,000 \\
Negatif Ranks & 15,50 & 465,00 & & \\
Positif Ranks & 0,00 & 0,00 & & \\
\hline
\end{tabular}

Tabel 4 Distribusi Frekuensi Responden Berdasarkan Usia

\begin{tabular}{cccc}
\hline No & Tingkat Usia (BKKBN) & Freukensi (n) & Persentase (\%) \\
\hline 1 & 20-35 Tahun & 30 & 100,0 \\
\hline & TOTAL & 30 & 100,0 \\
\hline
\end{tabular}

Tabel 5 Distribusi Responden Berdasarkan Tingkat Pendidikan

\begin{tabular}{cccc}
\hline No & Tingkat Pendidikan & Frekuensi (n) & Persentase (\%) \\
\hline 1 & SMA/SMK & 4 & 13,3 \\
2 & Diploma & 8 & 26,7 \\
3 & Sarjana & 18 & 60,0 \\
\hline & TOTAL & 30 & 100,0 \\
\hline
\end{tabular}

Berdasarkan tabel 1 menunjukkan tingkat kecemasan pre dilakukan intervensi senam hamil yang mendapat hasil tingkat kecemasan pada 30 responden ibu prenatal trimester III sebelum dilakukan intervensi sebagian besar ibu hamil mengalami kecemasan sedang yang berjumlah 19 responden (63,3\%). Tingkat kecemasan post dilakukan intervensi senam hamil ditunjukkan pada tabel 2 yang mendapat hasil sebagian besar responden mengalami kecemasan ringan yaitu sebanyak 18 orang (60,0\%). Pada tabel 3 menunjukkan pengaruh senam hamil terhadap tingkat kecemasan pada ibu prenatal trimester III yaitu dengan uji statistik Wilcoxon didapatkan hasil nilai Asymp. Sig. (2-tailed) atau p-value adalah 0,000 yang memiliki nilai yang lebih kecil dari $\alpha$ yaitu 0,05 yang berarti menunjukkan adanya pengaruh senam hamil terhadap tingkat kecemasan pada ibu prenatal trimester III maka Ha diterima. Semua responden pada penelitian ini berusia 20-35 tahun yang merupakan usia ideal perempuan untuk hamil menurut (BKKBN), yaitu mendapatkan hasil (100\%) yang ditunjukan pada tabel 4, hal tersebut menunjukkan responden pada penelitian ini masih dalam kategori usia produktif dan aman untuk menjalani kehamilan. Tingkat pendidikan responden ditunjukkan pada tabel 5 dimana sebagian besar responden memiliki tingkat pendidikan yang tinggi yaitu sarjana sebanyak 18 orang $(60,0 \%)$. 


\section{PEMBAHASAN}

\section{Tingkat Kecemasan Pre Dilakukan Intervensi Senam Hamil Di RSIA Cahaya Bunda Gerokgak Tabanan}

Tingkat kecemasan pre dilakukan intervensi senam hamil pada ibu prenatal trimester III menunjukkan bahwa tingkat kecemasan pada kategori kecemasan sedangyaitu sebanyak 19 orang $(63,3 \%)$. Hasil penelitian ini sejalan dengan penelitian Handayani (2015) yang mendapatkan hasil penelitian yaitu sebagian besar responden mengalami kecemasan sedang yaitu sebanyak 70,3\%. Hasil penelitian yang serupa juga didapat oleh Rakizah (2017) yang mendapatkan hasil sebagian besar ibu hamil memiliki kecemasan sedang yaitu $(45,5 \%)$, hal ini disebabkan karena ibu sudah pernah terpapar dengan pendidikan kesehatan tentang persiapan persalinan dan fisiologi persalinan baik melalui media internet atau dokter kandungan. Hasil ini sesuai dengan penjelasan Handayani, 2015 yang menyatakan bahwa tingkat pendidikan yang tinggi akan memperluas pandangan dan ruang lingkup pergaulan, sehingga tingkat pendidikan yang lebih tinggi akan mempermudah ibu untuk menerima informasi tentang kesehatan sehingga akan mempengaruhi tingkat kecemasan seseorang. Walaupun seperti itu bayang-bayang tentang persalinan yang semakin dekat tetap membuat ibu merasa cemas akan kondisi bayi yang akan dilahirkannya.Hal tersebut sejalan dengan penjelasan dari Ranita (2016) yang mengatakan bahwa kecemasan pada ibu hamil akan bertambah besar ketika jadwal persalinan semakin dekat, ibu mulai memikirkan proses persalinan serta kondisi bayi yang akan dilahirkan. Ibu yang mengalami kecemasan saat kehamilan usia trimester III akan mengalami peningkatan lepasnya hormon-hormon stres sehingga menyebabkan berbagai gangguan yang bisa terjadi pada ibu hamil salah satunya lemahnya kontraksi otot rahim, sehingga akan menyebabkan lamanya proses persalinan.

Jadi dapat disimpulkan bahwa ibu hamil pada penelitian ini memiliki kecemasan sedang, karena sebagian besar responden juga berpendidikan tinggi sehingga ibu hamil akan lebih luas dalam menerima informasi seputaran kesehatan dalam masa kehamilan,informasi tentang proses persalinan, sehingga hal tersebut dapat mempengaruhi tingkat kecemasan ibu hamil. Walaupun seperti itu bayang- 
bayang tentang persalinan yang semakin dekat tetap membuat ibu merasa cemas hal tersebut karena mereka merasa cemas terhadap proses persalinannya, dan cemas terhadap kondisi bayinya. Sehingga ibu hamil akan mencari cara untuk mengatasi masalah yang ia alami selama menjalani kehamilan yaitu dengan melakukan senam hamil untuk dapat mengurangi kecemasannya serta dapat menyehatkan fisiknya.

\section{Tingkat Kecemasan Post Dilakukan Intervensi Senam Hamil di RSIA Cahaya Bunda Gerokgak Tabanan}

Setelah dilakukan intervensi senam hamil selama 3 kali didapatkan hasil tingkat kecemasan ibu prenatal trimester III yaitu sebagian besar responden mengalami kecemasan ringan yaitu berjumlah 18 orang (60,0\%). Sehingga hasil tersebut menunjukkan terjadi penurunan tingkat kecemasan pada ibu prenatal trimester III sebelum dilakukan intervensi dan setelah dilakukan intervensi.Hasil penelitian ini sesuai dengan penjelasan dari Primasari(2017) yang mengatakan bahwa cara memutuskan siklus kecemasan dalam kehamilan, yaitu senam hamil, karena sebagai salah satu alternatif terapi yang dapat diberikan kepada ibu hamil.Senam hamil dapat meminimalkan efek-efek perubahan fisik dan psikis pada wanita hamil yang mengakibatkan berbagai keluhan.Hal tersebut juga sejalan dengan penjelasan dari Murbiah (2014) yang mengatakan bahwa kecemasan dalam kehamilan akibat beban psikologis dapat dikurangi ataupun dihilangkan dengan memeberikan pengobatan dan aktivitas olahraga selama kehamilan.Salah satu olahraga yang bisa dilakukan oleh ibu hamil adalah senam hamil.

Menurut Aliyah (2016) mengatakan bahwa bila dicermati lebih lanjut, sebenarnya dalam gerakan senam hamil terkandung efek relaksasi yang dapat menstabilkan kecemasan dan mengurangi rasa takut dengan cara relaksasi fisik dan mental, serta mendapatkan informasi yang mempersiapkan mereka untuk menghadapi persalinan dan kelahiran, sehingga dapat mengurangi perasaan cemas yang ibu hamil rasakan menjelang proses persalinannya. Senam hamil yang teratur dapat mengurangi ketidaknyamanan dan keluhan- keluhan ibu dalam menjalani masa kehamilan, seperti; nyeri punggung, mual, kejang tungkai, konstipasi, sesak nafas, serta kecemasan. Senam hamil juga berguna melancarkan sirkulasi darah, nafsu makan 
bertambah, pencernaan menjadi lebih baik, dan tidur menjadi lebih nyenyak (Aliyah, 2016).

Jadi dengan menurunnya nilai pretest ke nilai posttest membuktikan bahwa memang benar senam hamil memberikan pengaruh yang besar terhadap kondisi psikologis ibu hamil.Senam hamil mampu menurunkan kecemasan ibu hamil saat menjalani masa kehamilan. Sehingga ibu akan menjadi lebih rileks dan tenang, selain itu senam hamil juga dapat dapat menghilangkan nyeri pinggang, membuat lentur otot-otot yang nantinya berperan dalam proses melahirkan.

\section{Pengaruh Senam Hamil Terhadap Tingkat Kecemasan Pada Ibu Prenatal Trimester III}

Hasil pengujian data analisis statistik Wilcoxon Sign Rank Test pada 30 responden didapatkan nilai $\rho=0,000$ dengan demikian nilai $\rho$ lebih kecil dari $\alpha(5 \%)$ atau 0,05. Nilai-nilai tersebut mengandung makna bahwa ada pengaruh yang signifikan senam hamil terhadap tingkat kecemasan pada ibu prenatal trimester III di RSIA Cahaya Bunda Gerokgak Kabupaten Tabanan.Hasil penelitian ini menyatakan bahwa ada pengaruh senam hamil terhadap tingkat kecemasan pada ibu prenatal trimester III. Hasil penelitian ini sejalan dengan hasil penelitian yang dilakukan oleh Farida et al, 2017 yang mendapat hasil penelitian yaitu terdapat perbedaan rata-rata tingkat kecemasan antara pretest dan posttest pada kelompok senam hamil dan tidak senam hamil. Hal ini dapat dilihat dari $p$-value $<0,05$, yang berarti terdapat penurunan tingkat kecemasan pada kelompok senam hamil. Hal tersebut juga sejalan dengan penelitian dari Aliyah Janatin, 2016 didapatkan hasil pengujian perbedaan tingkat kecemasan sebelumdan setelah pemberian senam hamil menggunakan uji Wilcoxon diperoleh nilai signifikansi $p=0,000$. Karena nilai $p<0,05$ maka dapat disimpulkan bahwa ada perbedaan yang bermakna nilai tingkat kecemasan sebelum pemberian senam hamil dan setelah pemberian senam hamil di puskesmas Samata Kabupaten Gowa. Berdasarkan hal tersebut maka dapat dikatakan bahwa terdapat pengaruh pemberian senam hamil terhadap tingkat kecemasan ibu hamil.

Penelitian yang serupa juga dilakukan oleh Hardianti (2015) yang mendapat hasil penelitian yaitu terdapat perbedaan yang signifikan skor kecemasan ibu primigravida Trimester III yang mengikuti senam hamil maupun dengan yang tidak 
mengikuti senamhamil. Dilihat dari nilaip-value sebesar 0,01 dimana $<0,05$, karena $<0,05$ maka terdapat perbedaan yang signifikan skorkecemasan ibu primigravida TM III yang mengikuti senam hamil maupun denganyang tidak mengikuti senam hamil di BPS Azizah Cangkringan Sleman. Haltersebut menunjukkanadanya pengaruh senam hamil terhadap tingkat kecemasan pada ibu hamil.Menurut Sofian (2013) senam hamil menjadi salah satu usaha untuk menjaga kesehatan ibu hamil, selain mengkonsumsi makanan yang sehat, serta mengatur waktu untuk istirahat yang cukup.Perasaan takut dan cemas pada masa kehamilan dapat menimbulkan ketegangan jiwa dan fisik, yang dapat menyebabkan otot-otot dan persendian menjadi kaku sehingga mengganggu kesehatan ibu dan janin.

Pemberian senam hamil pada latihan releksasi akan menimbulkan efek relaks yang melibatkan syaraf parasimpatis dalam sistem syaraf pusat. Salah satu fungsi syaraf parasimpatis ini adalah menurunkan produksi hormon adrenalin atau epinefrin (hormon stres) dan meningkatkan skresi hormon noradrenalin atau norepinefrin (hormon relaks) sehingga terjadi penurunan kecemasan serta ketegangan pada ibu hamil yang mengakibatkan ibu hamil menjadi lebih relaks dan tenang, (Murbiah, 2014).Ibu hamil saat melakukan aktivitas fisik seperti senam hamil disiang hari dapat meningkatkan produksi hormon serotonin, hormon serotonin dihasilkan oleh kelenjar, sistem saraf pusat, dan platelet darah pineal saat tubuh terpapar rangsangan cahaya fungsinya yaitu sebagai neurotransmitter yang dapat mempengaruhi emosi dan tidur ibu. Secara fisiologis relaksasi pernafasan dan relaksasi progresif dapat menurunkan hormon adrenalin sehingga terjadi penurunan detak jantung, irama nafas, tekanan darah, ketegangan otot, dan tingkat metabolisme tubuh yang menyebabkan ibu menjadi lebih tenang seiring dengan menurunnya kecemasan, (Murbiah,2014).

Senam hamil mengandung gerakkan relaksasi sehingga bermanfaat untuk mengurangi kecemasan dan ketegangan fisik maupun mental ibu dalam menjalani kehamilan dan menghadapi persalinan, (Suwignyono, 2011)karena di sini akan dipelajari cara bernapas dan cara mengedan yang benar. Senam sebelum melahirkan juga mengoptimalkan fisik ibu, serta memelihara dan menghilangkan keluhankeluhan yang terjadi akibat proses kehamilan.Bila ibu hamil melakukan latihan 
senam hamil tersebut dengan benar, akan terasa efek relaksasi pada ibu hamil yang berguna untuk mengatasi kecemasan dan ketegangan yang ia rasakan selama kehamilan berlangsung(Aliyah,2016).

Salah satu faktor yang membuat ibu hamil sadar akan maanfaat senam hamil yang begitu besar bagi kesehatan fisik dan mental ibu hamil adalah pendidikan. Menurut Aliyah( 2016)tingkat pendidikan dan pengetahuan ibu mempengaruhi keikutsertaan ibu dalam senam hamil. Semakin tinggi pengetahuan ibu hamil tentang senam hamil, maka makin tinggi pula minat ibu dalam melakukan senam hamil. Orang yang mempunyai pendidikan tinggi akan memberikan respon yang lebih rasional dibandingan dengan orang yang tidak berpendidikan, dan latar belakang pendidikan juga yang mempengaruhi faktor cara berfikir seseorang. Hal ini selanjutnya akan menunjukkan kesadaran dan usaha pencapaian atau peningkatan derajat kesehatan fisik maupun psikologis yang lebih baik. Sehingga mereka akan mencari cara untuk mengurangi masalah salah satunya kecemasan yang mereka alami selama kehamilan yaitu dengan melakukan senam hamil.

Dalam penelitian ini sebagian besar responden berpendidikan sarjana yaitu sebesar $(60,0 \%)$ dan diploma sebesar $(26,7 \%)$ sehingga ibu hamil sadar akan manfaat senam hamil untuk mengurangi masalah-masalah dalam masa kehamilan yaitu salah satunya kecemasan. Hal ini sejalan dengan penelitian yang dilakukan Farida et al, 2017 di RSIA Sakina Idaman Sleman D.I Yogyakarta yaitu sebagian besar responden berpendidikan sarjana yaitu 46,4\%, DIII berjumlah 25\%, S2 berjumlah 7,14\%. Menurut penelitian Mayasari et altahun 2018 di Puskesmas Bahu Kecamatan Malalayang Kota Manado yang mendapatkan hasil dalam penelitian tersebut yaitu pendidikan dan kecemasan ibu hamil primigravida trimester III diperoleh nilai $\rho$ value $=0,420$ yang artinya tidak ada hubungan antara pendidikan dengan kecemasan ibu hamil primigravida trimester III,dikarenakan ibu hamil di Puskesmas Bahu lebih banyak yang memiliki pendidikan tinggi yaitu sebanyak 96,4\%.

Jadi dapat dikatakan walaupun memiliki pendidikan yang tinggi perasaan cemas dan bayang-bayang tentang proses persalinan bagi seorang ibu yang akan melahirkan adalah hal yang wajar. Sebagian besar ibu hamil pada penelitian ini 
memiliki pendidikan tinggi dan mengikuti senam hamil karena mengetahui manfaat yang diberikan pada kesehatan fisik dan mentalnya selama masa kehamilan.Sehingga ibu hamil yang sebelumnya memiliki kecemasan tinggi dan sedang mengalami penurunan tingkat kecemasan setelah dilakukan senam hamil.

Senam hamil dapat dilakukan oleh ibu hamil yang sehat fisik dan tidak memiliki gangguan pada kandungannya. Kematangan organ reproduksi seperti rahim dipengaruhi oleh usia. Menurut Fatimah S, 2015rentang usia yang paling baik untuk hamil antara 20-25 tahun. Kehamilan dibawah usia tersebut mengandung resiko fisik 2-5 kali dibandingkan dengan usia kehamilan ideal, dan resiko tersebut akan kembali meningkat setelah usia 35 tahun. Permasalahan medis yang mungkin terjadi adalah anemia, tekanan darah tinggi, persalinan prematur dan bedah cesar saat melahirkan bayinya. Sebaliknya, kehamilan di atas usia 35 tahun dapat menimbulkan resiko yang tinggi terhadap jiwa ibu maupun anak yang akan dilahirkannya. Meningkatkan angka kematian ibu (AKI), kesulitan persalinan dan cacat kromosom.

Dalam penelitian ini sebagian besar responden berusia 20-35 tahun yaitu sebesar $100.0 \%$ dan ini membuktikan usia responden tersebut masih dalam kategori usia produktif. Sehingga dapat dilakukan senam hamil karena keadaan ibu hamil tidak terlalu beresiko untuk diberikan senam. Hasil tersebut sejalan dengan penelitian yang dilakukan oleh Hardianti (2015) di BPS Azizah CangkringanSleman didapatkan datajumlah responden berusia 20-35 tahun yaitu sebanyak 30responden (100\%) dan tidak ada responden yang berusia $<20$ tahun dan $>35$ tahun. Ini menunjukan bahwa ibu primigravida masuk kategori masih muda dan masuk masa produktif.Penelitian yang lain yaitu peneltian dari Aliyah Jannatin, 2016 di Puskesmas Samata Kabupaten Gowa dimana responden dalam penelitian tersebut sebagian besar dalam rentang usia 20-35 tahun yaitu sebanyak $(81,8 \%)$, usia $<20$ berjumlah 1 orang dan usia $>35$ tahun sebanyak 3 orang, yang menunjukkan sebagian besar responden dalam penelitian tersebut sebagian besar pada usia produktif.

Pendidikan dan usia merupakan salah satu hal yang membuat ibu hamil tertarik dan bisa melakukan senam hamil untuk mengurangi keluhan-keluhan yang dialami selama masa kehamilannya salah satunya yaitu kecemasan. Ibu hamil setelah 
melakukan senam hamil mengalami penurunan tingkat kecemasan, yang membuktikan bahwa memang benar ada pengaruhnya senam hamil terhadap tingkat kecemasan ibu prenatal trimester III. Selain untuk menurunkan kecemasan pada ibu hamil, senam hamil juga memiliki manfaat lain yang juga baik untuk kesehatan ibu dan janin. Sehingga ibu hamil yang telah memasuki usia kandungan trimester III disarankan untuk mengikuti senam hamil, karena memberikan dampak positif terhadap kondisi kandungan ibu, dan dapat memperlancar proses persalinannya.

\section{SIMPULAN}

Berdasarkan penelitian dan pembahasan mengenai pengaruh senam hamil terhadap tingkat kecemasan pada ibu prenatal trimester III di RSIA Cahaya Bunda Gerokgak Tabanan, maka dapat diambil kesimpulan tingkat kecemasan pre dilakukan intervensi senam hamil yaitu paling banyak responden mengalami kecemasan sedang, tingkat kecemasan responden post dilakukan intervensi senam hamil selama 3 kali yaitu sebagian responden mengalami penurunan tingkat kecemasan menjadi kecemasan ringan. Hasil uji statistik mendapatkan hasil ada pengaruh yang disignifikan dilakukannya intervensi senam hamil terhadap tingkat kecemasan pada ibu prenatal trimester III di RSIA Cahaya Bunda Gerokgak Tabanan, dengan nilai $p$ value $<0,05$

\section{DAFTAR PUSTAKA}

Aliyah,Jannatin.(2016). Pengaruh Pemberian Senam Hamil Terhadap Tingkat Kecemasan dan Kualitas Tidur Ibu Hamil di Puskesmas Samata Kabupaten Gowa.Available dari: https://www.unesa.ac.id. Diakses tanggal 14 Januari 2019.

Diskes Bali.(2017). Profil Kesehatan Dinas Kesehatan Provinsi Bali.Available dari: www.diskes.baliprov.go.id: Diakses tanggal 24 Oktober 2018.

Farida et al. (2017). Senam Hamil Berpengaruh terhadap Tingkat Kecemasan pada Primigravida Trimester III di RSIA Sakina Idaman Slemman,D.I Yogyakarta. Available: http://ejournal.alaamata.ac.id. Diakses tanggal 26 Oktober 2018.

Fatimah,S. (2015). Perbandingan Tingkat Kecemasan Ibu hamil antara Primigravida dan Grandemultigravida di Puskesmas Pacet Kabupaten Bandung.Available dari: Repository.unisba.ac.id. Diakses tanggal 1 Februari 2019. 
Handayani. (2015). Faktor-Faktor Yang Berhubungan Dengan Tingkat Kecemasan Menjelang Persalinan Pada Ibu Primigravida Trimester III di Wilayah Kerja Puskesmas Lubuk Buaya Padang Tahun 2012.Available dari: https://studylibid.com. Diakses tanggal 14 Juli 2019

Hardianti.(2015). Pengaruh Keikutsertaan Senam Hamil Terhadap Kecemasan Primigravida Trimester III Dalam Menghadapi Persalinan di BPS Azizah Cangkringan Sleman.Available dari:https://digilb.unisayogya.ac.id. Diakses tanggal 1Februari $\underline{2019}$

Hartaty,Diana. (2016). Hubungan Keikutsertaan Senam Hamil Dengan Kecemasan Primigravida Dalam Menghadapi Persalinan.Available dari :https://le-journal.ibi.or.id. Diakses tanggal 28 Oktober 2018

Herdman,T.H. (2016). Nanda Diagnosis Keperawatan Definisi dan Klasifikasi 2015-2017. Jakarta: EGC

Heriani. (2016). Kecemasan Dalam Menjelang Persalinan Ditinjau Dari Paritas, Usia, dan Tingkat Pendidikan. Available dari: https:/lejournal.stikesaisyah.ac.id. Diakses tanggal 29 Oktober 2018

Kemenkes RI. (2015). Profil Kesehatan Indonesia 2015.Available dari: www.depkes.go.id. Diakses tanggal 5 November 2018.

Kemkes. (2017). Capaian Kinerja Kemenkes RI Tahun 2015-2017. Available dari: www.depkes.go.id. Diakses tanggal 24 Oktober 2018.

Kuswanti,Ina.(2014). Asuhan Kehamilan.Yogyakarta: Pustaka Pelajar

Locchart dan Saputra. (2014). Asuhan Kebidanan Kehamilan Fisiologi dan Patologi.Tanggerang: Binarupa Aksara

Mardjan.(2016). Pengaruh Kecemasan Pada Kehamilan Primipara Remaja. Pontianak: Abrori Institute

Mayasari et al. (2018).Analisis Faktor-Faktor Yang Berperan Pada Kecemasan Ibu Hamil Primigravida Trimester III di Puskesmas Bahu Kecamatan Malalayang Kota Manado. Available dari: https://ejournalhealth.com. Diakses tanggal 12 Juni 2019

Murbiah.(2014).Pengaruh Senam Hamil Terhadap Tingkat Kecemasan Primigravida Trimester III di Kota Palembang.Tesis. Yogyakarta: UGM

Nurdiansyah, Nia.(2011). Buku Pintar Ibu \& Bayi. Bukune: Jakarta

Nursalam.(2017). Metodelogi Penelitian Ilmu Keperawatan. Jakarta: Salemba Medika.

Primasari,N. (2017). Pengaruh Senam Hamil Terhadap Tingkat Kecemasan Primigravida Menghadapi Persalinan Di Rumah Bersalin Wilayah Bekasi. Available dari: https://studylibid.com. Diakses tanggal 14 Januari 2019 
Rakizah.(2017). Gambaran Pengetahuan Dan Kecemasan Ibu Hamil Trimester Iii Dalam Menghadapi Persalinan Di Wilayah Kerja Puskesmas Muara Aman Kecamatan Lebong Utara, Kabupaten Lebong.Available dari: https://jurnal.unived.ac.id. Diakses tanggal 16 Julin 2019

Ranita.(2016).Pengaruh Belly Dance Terhadap Tingkat Kecemasan Ibu Hamil Primigravida Trimester III (Studi Kasus Di Bpm Ranting 3 Kota Semarang).Available dari: http://eprints.undip.ac.id. Diakses tanggal 3 Juli 2019

Sofian,Amru.(2013). Sinopsis Obstetri Jilid 2. Jakarta: EGC

Suwignyono.(2011). Panduan Super Lengkap Hamil Sehat. Semarang: PT Niaga Swadaya

Verbeek, $\mathrm{T}$ et al.(2015). Anxiety and depression during pregnancy ini Central America.Available at: https://www.ncbi.nlm.nih.gov. Diakses tanggal 2 Januari 2019 